\title{
Induction of Platelet-derived Growth Factor A-chain and c-myc Gene Expressions by Angiotensin II in Cultured Rat Vascular Smooth Muscle Cells
}

\author{
Allen J. Naftilan, Richard E. Pratt, and Victor J. Dzau \\ Molecular and Cellular Vascular Research Laboratory, Division of Vascular Medicine and Atherosclerosis, Department of Medicine, \\ Brigham and Women's Hospital and Harvard Medical School, Boston, Massachusetts 02115
}

\begin{abstract}
Recently, angiotensin II (Ang II) has been shown to cause hypertrophy of cultured quiescent rat aortic smooth muscle (RASM) cells. This observation along with the demonstration of angiotensinogen mRNA in the vessel wall has led us to postulate a role for vascular angiotensin in hypertensive blood vessel hypertrophy. To investigate further the possible molecular mechanisms, we examined the effect of Ang II on the expression of two genes known to be involved with cellular growth response. Near-confluent RASM cells were made quiescent by 48-h exposure to a defined serum-free medium. Ang II $\left(10^{-6}\right.$ to $\left.10^{-11} \mathrm{M}\right)$ resulted in an induction of the protooncogene c-myc mRNA within 30 min which persisted for $6 \mathrm{~h}$. Interestingly, $6 \mathrm{~h}$ after the addition of Ang II, platelet-derived growth factor (PDGF) A-chain mRNA expression was elevated, peaked in $9 \mathrm{~h}$, and persisted for $11 \mathrm{~h}$. This was accompanied with a 15-20-fold increase in PDGF concentration in the culture medium. These effects were dose-dependent and were blocked by saralasin. Whereas the inhibition of protein synthesis by cycloheximide resulted in a stabilization of c-myc mRNA, cycloheximide abolished the elevation of the PDGF A-chain mRNA. Taken together, our data show that exposure of RASM cells to Ang II results in the sequential activation of c-myc and PDGF A-chain mRNA expressions. This sequential activation of protooncogene and growth factor gene may be an important mechanism in angiotensin-induced smooth muscle growth and hypertrophy.

Introduction
\end{abstract}

One of the major structural adaptations to an elevated blood pressure is the growth of vascular smooth muscle. It has been proposed that this structural change may play an important role in amplifying and perpetuating hypertension (1). Morphologic studies demonstrated that in the aorta this increase in smooth muscle mass is due to hypertrophy rather than hyperplasia (2), whereas in the smaller-resistance vessels hyperplasia may be the principal process (3). The factors that initiate and

Address reprint requests to Dr. Dzau, Molecular and Cellular Vascular Research Laboratory, Brigham and Women's Hospital, 75 Francis Street, Boston, MA 02115.

Received for publication 20 September 1988 and in revised form 20 December 1988.

J. Clin. Invest.

(C) The American Society for Clinical Investigation, Inc. $0021-9738 / 89 / 04 / 1419 / 06 \$ 2.00$

Volume 83, April 1989, 1419-1424 maintain the vascular growth response have not been fully elucidated. The hypertrophy seen in the aorta may be a response, at least in part, to hemodynamic forces since it has been shown that the reduction in blood pressure of the spontaneously hypertensive rat (SHR) ${ }^{1}$ with nonspecific vasodilators (e.g., hydralazine) prevents, in part, the increase in smooth muscle mass (4). However, evidence also suggests that nonhemodynamic factors may play a role in the vascular hypertrophy of hypertension. A leading candidate for such a humoral factor is angiotensin II (Ang II). The blockade of Ang II production with a converting-enzyme inhibitor, captopril, in the SHR results in a reduction in smooth muscle hypertrophy which is significantly greater than that observed for a comparable reduction in blood pressure with hydralazine treatment (4). Indeed, the direct stimulating effect of Ang II on vascular myocyte growth has been demonstrated by Geisterfer et al. (5) using cultured rat aortic smooth muscle cells and by Campbell-Boswell and Robertson (6) using cultured human aortic smooth muscle cells.

In recent years evidence has been accumulating that the protooncogenes are important regulators of cell growth $(7,8)$. Numerous investigators have demonstrated that, when quiescent cells in culture are stimulated to grow by the addition of serum or specific growth factors, rapid and transient inductions of the protooncogenes c-fos and c-myc (7-11) occur. Furthermore, the inhibition of c-fos mRNA translation by antisense c-fos transcription has been shown to inhibit fibroblast growth $(12,13)$. Since it has been reported that angiotensin can induce c-fos mRNA expression in the rat aortic smooth muscle cells $(14,15)$, it is a logical extension to explore the influence of angiotensin on c-myc expression. In addition, the smooth muscle mitogen, platelet-derived growth factor (PDGF) has been shown recently to be expressed in vascular smooth muscle cells (16) and postulated to be involved in the autocrine regulation of the growth of these cells. We believe that it would be additionally important to study whether PDGF expression is involved in the smooth muscle growth responses to angiotensin. We report herein that Ang II leads to a rapid increase in the expression of the protooncogene c-myc mRNA. A delayed induction of PDGF A-chain mRNA accompanied by an increase in PDGF secretion is also observed. Taken together, these findings may have important implications in the mechanism of Ang II on the development of the increased smooth muscle mass seen in hypertension.

1. Abbreviations used in this paper: Ang II, angiotensin II; PDGF, platelet-derived growth factor; RASM, rat aortic smooth muscle; SHR, spontaneously hypertensive rat. 


\section{Methods}

Cell culture. Rat aortic smooth muscle cells (RASM) (passages 8-18) were produced according to the method of Gunther et al. (17) and maintained in Dulbecco's modified Eagle's medium (DME, Gibco, Grand Island, NY) with $10 \%$ fetal calf serum, penicillin $(100 \mathrm{U} / \mathrm{ml})$, streptomycin $(100 \mu \mathrm{g} / \mathrm{ml})$ and $25 \mathrm{mM}$ Hepes, $\mathrm{pH}$ 7.4. Cells were incubated at $37^{\circ} \mathrm{C}$ in a humidified atmosphere of $95 \%$ air $/ 5 \% \mathrm{CO}_{2}$. In preparation for experiments, the cells were made quiescent by placing them in a defined serum-free medium containing insulin $\left(5 \times 10^{-7} \mathrm{M}\right.$, Sigma Chemical Co., St. Louis, MO), transferrin $(5 \mu \mathrm{g} / \mathrm{ml}$, Sigma Chemical Co.), and ascorbate $(0.2 \mathrm{mM}$, Sigma Chemical Co.). This medium has been shown by others to maintain smooth muscle cells in a quiescent, noncatabolic state for an extended period of time (18). Ang II and [Sar-1, Ala-8]-Ang II (saralasin) were dissolved in $20 \mathrm{mM}$ acetic acid at a concentration of $2 \mathrm{mg} / \mathrm{ml}$. Cycloheximide was dissolved in distilled water at a final concentration of $4 \mathrm{mg} / \mathrm{ml}$. These compounds were added independently or together, to the media of cultured RASM at zero time.

$R N A$ isolation. Cells were harvested at the indicated time points by the addition of $0.05 \%$ trypsin and $0.53 \mathrm{mM}$ EDTA. The detached cells were pellet by centrifugation at $2,000 \mathrm{rpm}$ for $10 \mathrm{~min}$, frozen in liquid nitrogen, and stored at $-70^{\circ} \mathrm{C}$ until used. Total RNA was isolated as described (19), quantitated by absorbance at $260 \mathrm{~nm}$, and stored at $-70^{\circ} \mathrm{C}$ for future use.

Northern gel analysis. RNA was lyophilized, denatured with $7.2 \%$ formaldehyde and $50 \%$ formamide $(20 \mu \mathrm{l} / 25 \mu \mathrm{g}$ of RNA), and run on $1.5 \%$ agarose gels containing $0.66 \mathrm{M}$ formaldehyde in a buffer of 20 mM 3-[ $N$-morpholino]propanesulfonic acid (MOPS), $5 \mathrm{mM}$ sodium acetate, and $1 \mathrm{mM}$ EDTA, pH 7.0. The gels were electrophoresed at $100 \mathrm{~V}$ for $4 \mathrm{~h}$ with constant circulation of the buffer. Gels were stained with ethidium bromide, photographed, and transferred to nylon filters (Gene Screen, New England Nuclear, Boston, MA) in 20x SSC (1X SSC equals $0.15 \mathrm{M}$ sodium chloride, $0.15 \mathrm{M}$ sodium citrate, $\mathrm{pH}$ 7.0).

Gels were baked in a vacuum oven at $80^{\circ} \mathrm{C}$ for $2 \mathrm{~h}$ and prehybri- dized at $42^{\circ} \mathrm{C}$ for $3-4 \mathrm{~h}$ in a buffer containing $5 \times$ Denhardt's, $5 \times \mathrm{SSC}$, $50 \%$ formamide, $1 \%$ SDS, $200 \mu \mathrm{g} / \mathrm{ml}$ salmon sperm DNA, $100 \mu \mathrm{g} / \mathrm{ml}$ yeast tRNA, and $1.0 \mu \mathrm{g} / \mathrm{ml}$ each of poly $A$ and poly $C$. The blots were then hybridized in the same buffer at $42^{\circ} \mathrm{C}$ overnight with ${ }^{32} \mathrm{P}$-labeled DNA. After hybridization the blots were washed at room temperature in $2 \times \mathrm{SSC}, 0.1 \% \mathrm{SDS}$ and then with $\mathrm{C.2} \times \mathrm{SSC}, 0.1 \% \mathrm{SDS}$ at $65^{\circ} \mathrm{C}$. Autoradiograph was performed with Kodax XAR-5 film with intensifying screens (DuPont Co., Wilmington, DE) at $-70^{\circ} \mathrm{C}$. The developed film was then scanned with a microdensitometer (LKB Instruments, Inc., Gaithersburg, MD).

Labeling of $c D N A$. The following probes were used: $(a)$ the mouse c-myc full-length cDNA (20); (b) the human PDGF A-chain full-length cDNA (kindly supplied by Dr. C.-H. Heldin, Ludwig Institute for Cancer Research, Uppsala, Sweden) (21); and (c) a 1.2-kb Pst fragment of the v-sis gene (22). DNA probes were labeled with $25 \mu \mathrm{Ci}$ of $\left[{ }^{32} \mathrm{P}\right]$ deoxycytidine $5^{\prime}$-triphosphate $(1,000-1,500 \mathrm{Ci} / \mathrm{mmol}$; New England Nuclear) using the random oligonucleotide method as described (23). The ${ }^{32} \mathrm{P}$-labeled DNA was purified by Sephadex G-50 chromatography.

Determination of PDGF concentration. $24 \mathrm{~h}$ after addition of angiotensin or vehicle, the culture media were collected. The PDGF concentrations in the media were measured directly by a radioreceptor assay (24) (kindly performed by Dr. P. DiCorleto, Cleveland Clinic, Cleveland, $\mathrm{OH})(24)$. This assay measures the specific binding of PDGF to human foreskin fibroblast cells. The radiolabeled ( $\left.{ }^{125} \mathrm{I}\right)$ and cold ligand employed is PDGF A-B heterodimer isolated from human platelets. Heldin et al. (25) showed that PDGF A-A homodimer competed effectively with the binding of ${ }^{125} \mathrm{I}$-labeled PDGF A-B heterodimer to the fibroblast receptor employed in this assay.

\section{Results}

Effects of Ang II on expression of the c-myc gene. In quiescent RASM cells, a low basal expression of c-myc mRNA could be detected. In response to Ang II a rapid induction of c-myc
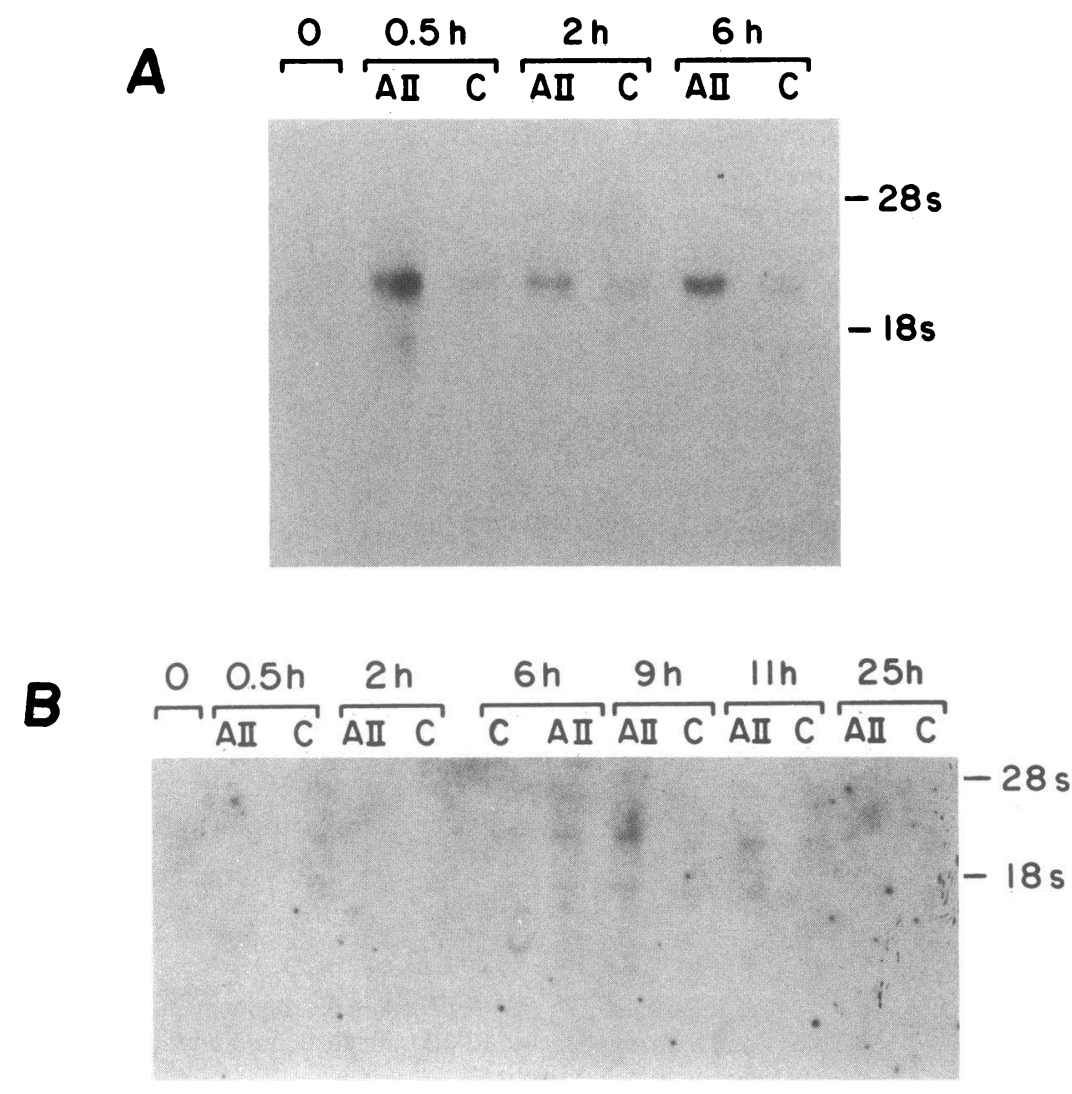

Figure 1. Time course of induction of c-myc and PDGF A chain mRNAs by Ang II ( $A I I)$. Quiescent RASM cells were exposed to angiotensin II ( $A I I$, $10^{-6} \mathrm{M}$ ) or vehicle (control) for the times indicated. Total RNA $(25 \mu \mathrm{g})$ was analyzed by Northern blotting and hybridized to ${ }^{32} \mathrm{P}$-labeled c-myc $(A)$ and PDGF A-chain $(B)$ cDNAs. The positions of the $28 \mathrm{~S}$ and $18 \mathrm{~S}$ ribosomal RNAs are indicated at the right of the blot. 
mRNA was observed within 30 min which persisted for $6 \mathrm{~h}$ (Fig. $1 A$ ). This response was dose-dependent over the dose range of angiotensin examined $\left(10^{-6}\right.$ to $\left.10^{-11} \mathrm{M}\right)$ and the specific Ang II competitive inhibitor saralasin completely blocked the Ang II-induced increase in c-myc mRNA (data not shown). This use in c-myc appeared to be biphasic. This pattern was reproducible.

To elucidate the possible mechanisms underlying these responses, Ang II was added in the presence of the protein synthesis inhibitor cycloheximide (final concentration of 40 $\mu \mathrm{g} / \mathrm{ml}$ ). Cycloheximide had no effect on baseline c-myc mRNA levels in unstimulated cells (data not shown). In contrast, cycloheximide resulted in a greater and more prolonged increase of the c-myc mRNA (Fig. $2 A$ ). This result suggests that the induction of c-myc mRNA by Ang II is not dependent on de novo protein synthesis. In fact, the further increase in $c-m y c$ mRNA levels in the presence of cycloheximide probably

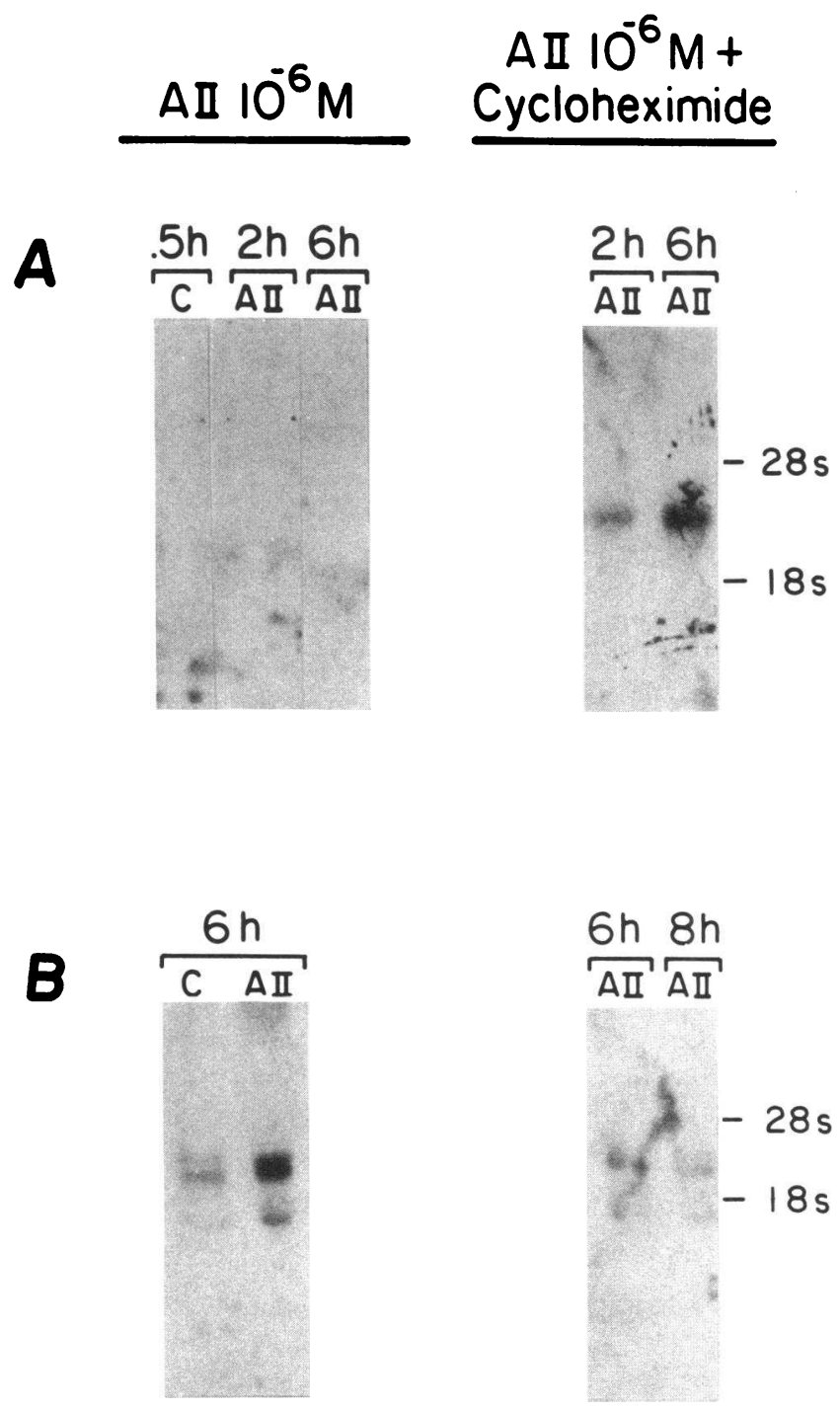

Figure 2. Effect of cycloheximide on the accumulation of c-myc and PDGF A-chain mRNAs in response to Ang II $(A I I)$. Quiescent RASM cells were treated with control, Ang II $\left(10^{-6} \mathrm{M}\right)$, or Ang II plus cycloheximide $(40 \mu \mathrm{g} / \mathrm{ml})$ for the indicated times. Total RNA $(25 \mu \mathrm{g})$ was analyzed by Northern blotting for the presence of $c-m y c$ $(A)$ or PDGF A-chain $(B)$ mRNA as described. reflects a stabilization of the mRNA presumably through the inhibition of the synthesis of ribonucleases which degrade the mRNA.

Effects of Ang II on expression of the PDGF A-chain gene. As previously reported (16), cultured RASM cells express multiple PDGF A-chain transcripts. We observed in unstimulated cells the presence of the 1.7- and 2.3-kb transcripts. Occasionally the upper band can be resolved into two bands of $\sim 2.5$ and $2.3 \mathrm{~kb}$. PDGF B-chain mRNA, however, was not detected at any time point in our experiments (data not shown). The addition of Ang II to RASM cells resulted in a delayed stimulation of PDGF A-chain mRNA expression, first detectable at 4-6 $\mathrm{h}$ (Fig. $1 \mathrm{~B}$ ). The level peaked at $9 \mathrm{~h}$ and persisted until 11 $h$ after exposure to Ang II. The induction of PDGF A-chain gene expression by Ang II was dose-dependent (Fig. 3, left and middle). The lowest concentration of Ang II capable of stimulating PDGF A-chain mRNA expression was $10^{-11} \mathrm{M}$. The $\mathrm{EC}_{50}$ was $10^{-9} \mathrm{M}$. The effect was Ang II receptor-specific in that it was completely blocked by the Ang II antagonist, saralasin (Fig. 3, right). In contrast to the result with c-myc mRNA, the blockade of protein synthesis with cycloheximide completely inhibited the induction of PDGF A-chain by Ang II (Fig. 2 B). However, cycloheximide alone had no effect on the baseline expression of PDGF A-chain mRNA in unstimulated cells.

Effects of Ang II on the release of PDGF by RASM. Under basal conditions, quiescent RASM cells secrete low levels of PDGF $(0.15 \pm 0.06 \mathrm{ng} / \mathrm{ml}$ per $24 \mathrm{~h})$. However, in response to Ang II, this increases $15-20$-fold $(2.15 \pm 0.05 \mathrm{ng} / \mathrm{ml}$ per $24 \mathrm{~h}, n$ $=3, P<0.001$, Fig. 4). In this assay the PDGF employed as the radiogland and in the standard curve was the A-B heterodimer. Heldin et al. (25) showed that the A-A homodimer competed effectively with the A-B heterodimer for binding to the fibroblast receptor employed in this assay, albeit less powerfully than the heterodimer itself. Thus, the values depicted in Figs. 3 and 4 are probably an underestimate of the actual PDGF Achain levels. In contrast the fold increase of PDGF should be an accurate representation of the magnitude of the response to angiotensin.

\section{Discussion}

In these studies we have demonstrated that the potent vasoconstrictor Ang II can induce the expression of the protooncogene c-myc along with the gene encoding the A-chain of PDGF. In addition, angiotensin has been shown to induce c-fos mRNA expression $(14,15)$. Our data demonstrate that the increase in c-myc mRNA expression does not require protein synthesis and occurs within $30 \mathrm{~min}$ after the addition of Ang II. In contrast, the increase in PDGF A-chain mRNA occurs 4-6 $\mathrm{h}$ after the addition of Ang II and requires protein synthesis. These molecular responses are dose-dependent and are specific since they can be blocked by the specific Ang II inhibitor, saralasin.

In recent years it has become clear that the protooncogene c-myc is an important regulator of cell growth $(7,8)$ and is activated in numerous cell types in response to growth-promoting agents (7-11). In addition, cultured smooth muscle cells are capable of producing PDGF A-A homodimer $(26,27)$. In this study, angiotensin stimulated the synthesis and release of PDGF A chain by these cells. Since the A-A homodimer of PDGF is mitogenic towards smooth muscle cells (26) it is possible that the increase in c-myc and PDGF A-chain expres- 

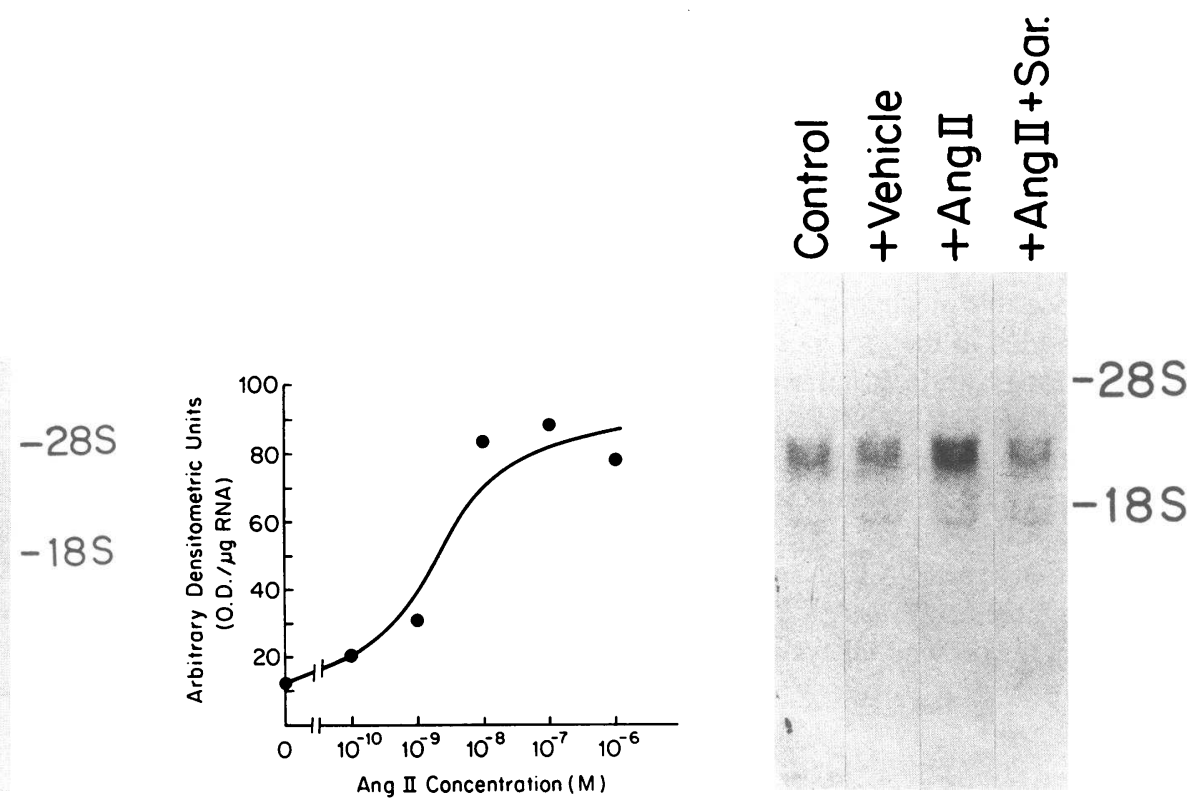

Figure 3. (Left and middle) Dose-response relationship of Ang II on the expression of PDGF A-chain. Quiescent RASM cells were exposed to Ang II $\left(10^{-10}\right.$ to $\left.10^{-6} \mathrm{M}\right)$ or vehicle $(0 \mathrm{M})$ for $8 \mathrm{~h}$. Total RNA $(25 \mu \mathrm{g})$ was analyzed by Northern blotting and hybridized to ${ }^{32} \mathrm{P}-\mathrm{labeled}$ PDGF A-chain cDNA (left). The resultant autoradiogram was quantitated by densitometry (middle). (Right) Effect of saralasin on Ang II induction of PDGF A-chain. Quiescent RASM cells were incubated in culture medium (control), plus vehicle, plus Ang II or Ang II plus saralasin for $8 \mathrm{~h}$. Total RNA $(25 \mu \mathrm{g})$ was analyzed by Northern blotting and hybridized to ${ }^{32} \mathrm{P}$-labeled PDGF A-chain cDNA. The position of the $28 \mathrm{~S}$ and $18 \mathrm{~S}$ ribosomal RNAs are indicated at the right of the blot.

sions seen in this study may, in part, mediate the growth promoting effect of Ang II.

An interesting issue raised by these observations is that, although Ang II induces the expressions of c-myc and PDGF A-chain mRNA, Geisterfer et al. (5) demonstrated that Ang II induces hypertrophy and tetraploidy but not hyperplasia. This suggests that although the induction of these factors by Ang II confers competence on the smooth muscle cells, it is insufficient to stimulate the cells to go through mitosis. The explanation for this observation is not clear. Since only PDGF A-A homodimer is stimulated by Ang II, the data suggest that the A-A homodimer is a less potent mitogen than its A-B or B-B counterparts. Indeed, Heldin et al. (25) and Escobeda et al. (28) have showed recently that the A-A homodimer is a less potent mitogen of fibroblast cells than the B-B homodimer or the A-B heterodimer. However, it should also be pointed out that, under a different culture condition (presence of serum) and using vascular smooth muscle cell from a different species, angiotensin has been reported to induce cellular hyperplasia (6). Thus, the growth response to angiotensin may be depen-

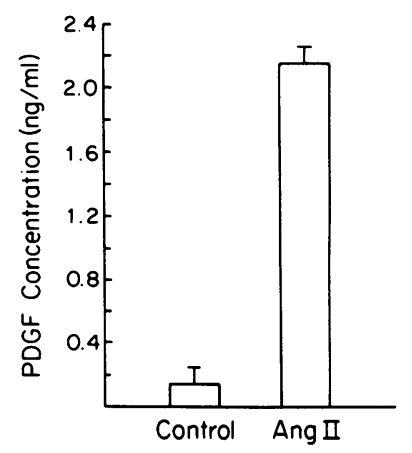

Figure 4. Effect of Ang II on the release of PDGF-like mitogen into conditioned media. Quiescent RASM cells were exposed to vehicle or Ang II for $24 \mathrm{~h}$. Media were then assayed for PDGF by the radioreceptor assay. The results are the average of three separate experiments. dent on the culture condition (e.g., other growth factors) and/ or the cell type. The elucidation of the mechanisms responsible for cellular hypertrophy vs. hyperplasia is a fundamental problem in cell biology (29).

If Ang II is responsible in part for the hypertensive smooth muscle growth, it is necessary to postulate a mechanism by which Ang II is activated in chronic hypertension. In most forms of chronic hypertension, e.g., SHR, plasma renin levels are normal or even low $(30,31)$, thus making it difficult to propose that an elevation of plasma Ang II levels is responsible for the smooth muscle growth. Yet, angiotensin-converting enzyme inhibition prevents vascular hypertrophy in these rats. Recently all of the components of the renin angiotensin system have been demonstrated to be present in the vascular wall ( 30 , 32). Since the angiotensinogen gene has been shown to be expressed in the thoracic aortic smooth muscle cell layer (33) as well as in the periadventitial fat tissue $(32,34)$, one may propose an autocrine or paracrine mechanism of angiotensin for the stimulation of smooth muscle cell growth. In some experimental models of hypertension, there is evidence to suggest that this tissue renin-angiotensin system is activated (31, 35 ). Therefore, it is attractive to speculate that increased vascular angiotensin production is involved in the vascular hypertrophy seen in these animals.

The data presented herein also demonstrate that protein synthesis is not necessary for the increase in the expression of c-myc mRNA. The mechanism of PDGF A-chain mRNA increase appears to be different since it is activated much later and its induction is blocked by the inhibition of protein synthesis. Since c-myc encodes a nuclear protein (36) it is possible that it may play a direct role in the induction of PDGF Achain expression, but we cannot rule out the possibility that other genes are also activated by Ang II and take part in the induction of PDGF A-chain expression. Our data do not indi- 
cate at what molecular level Ang II acts to increase the mRNAs of the genes studied. In most systems c-fos appears to be under transcriptional control $(8,9)$ and there is some data to suggest that $c-m y c$ is under postranscriptional control in serum activated smooth muscle cells (37). Since the cDNA for PDGF A-chain has only recently been cloned, the level at which its expression is controlled has not been studied. The Ang II-induced PDGF expression in RASM may be a useful system to examine this question.

In summary, our data demonstrate that along with many properties (including vasoconstriction, thirst stimulation, and stimulation of aldosterone secretion), angiotensin may also be an important growth-promoting agent of vascular smooth muscle cells. A broader implication of the results of this study may be that vasoactive hormones are potentially growth-promoting substances and may participate in hypertension by inducing hypertrophy as well as vasoconstriction. To our knowledge this is the first demonstration that PDGF expression is influenced by a vasoactive substance. The molecular mechanism by which Ang II stimulates c-myc and PDGF Achain mRNAs and the role of these genes in vascular hypertrophy will be the important subjects of future investigations.

\section{Acknowledgments}

The authors are grateful to Dr. Paul DiCorleto for performing the PDGF radioreceptor assays and thank Ms. Donna MacDonald and Ms. Nancy Beattie for their secretarial support in preparation of the manuscript.

This work was supported by National Institutes of Health grants HL-35610, HL-35792, HL-19259, and HL-35252, and National Institutes of Health Specialized Center of Research in Hypertensin HL-36568. Dr. Victor J. Dzau is an Established Investigator of the American Heart Association.

\section{References}

1. Folkow, B., M. Hallback, Y. Lundgren, R. Sivertsson, and L. Weiss. 1973. Importance of adaptive changes in vascular design for establishment of primary hypertension, studied in man and in spontaneously hypertensive rats. Circ. Res. 32(Suppl. 1):2-16.

2. Owens, G. K., and S. M. Schwartz. 1982. Alterations in vascular smooth muscle mass in the spontaneously hypertensive rat. Role of cellular hypertrophy, hyperploidy, and hyperplasia. Circ. Res. 51:280-289.

3. Mulvany, M. J., U. Baandrup, and H. J. Gundersen. 1985. Evidence for hyperplasia in mesenteric resistance vessels of spontaneously hypertensive rats using a three-dimension disector. Circ. Res. 57:794-800.

4. Owens, G. K. 1987. Influence of blood pressure on development of aortic medial smooth muscle hypertrophy in spontaneously hypertensive rats. Hypertension. 9:178-187.

5. Geisterfer, A. A. T., M. J. Peach, and G. K. Owens. 1988. Angiotensin II induces hypertrophy, not hyperplasia, of cultured rat aortic smooth muscle cells. Circ. Res. 62:749-756.

6. Campbell-Boswell, M., and A. L. Robertson, Jr. 1981. Effects of angiotensin II and vasopressin on human smooth muscle cells in vitro. Exp. Mol. Pathol. 35:265-276.

7. Marx, J. L. 1987. The fos gene as "master switch" [news]. Science (Wash. DC). 237:854-856.

8. Verma, I. M., and P. Sassone-Corsi. 1987. Proto-oncogene fos: complex but versatile regulation. Cell. 51:513-514.

9. Greenberg, M. E., and E. B. Ziff. 1984. Stimulation of 3T3 cells induces transcription of the c-fos proto-oncogene. Nature (Lond.). 311:433-438.
10. Greenberg, M. E., L. A. Greene, and E. B. Ziff. 1985. Nerve growth factor and epidermal growth factor induce rapid transient changes in proto-oncogene transcription in PC12 cells. J. Biol. Chem. 260:14101-14110.

11. Muller, R., R. Brovo, J. Burckhardt, and T. Curran. 1984. Induction of $\mathrm{c}$-fos gene and protein by growth factors precedes activation of c-myc. Nature (Lond.). 312:716-720.

12. Holt, J. T., T. V. Gopal, A. D. Moulton, and A. W. Nienhuis. 1986. Inducible production of c-fos antisense RNA inhibits $3 T 3$ cell proliferation. Proc. Natl. Acad. Sci. USA. 83:4794-4798.

13. Nishikura, K., and J. M. Murray. 1987. Antisense RNA of proto-oncogene c-fos blocks renewed growth of quiescent 3T3 cells. Mol. Cell. Biol. 7:639-649.

14. Kawahara, Y., M. Sunako, T. Tsuda, H. Fukuzaki, Y. Fukumoto, and Y. Takai. 1988. Angiotensin II induces expression of the c-fos gene through protein kinase $\mathrm{C}$ activation and calcium ion mobilization in cultured vascular smooth muscle cells. Biochem. Biophys. Res. Commun. 150:52-59.

15. Taubman, M. B., B. C. Berk, S. Izumo, R. W. Alexander, and B. Nadal-Ginard. 1987. Angiotensin II induction of c-fos mRNA in cultured rat aortic smooth muscle cells is independent of stimulation $\mathrm{Na}^{+} / \mathrm{H}^{+}$exchange. J. Mol. Cell. Cardiol. 19(Suppl. IV):S6. (Abstr.)

16. Sejersen, T., C. Betsholtz, M. Sjolund, C. H. Heldin, B. Westermark, and J. Thyberg. 1986. Rat skeletal myoblasts and arterial smooth muscle cells express the gene for the A chain but not the gene for the B chain (c-sis) of platelet-derived growth factor (PDGF) and produce a PDGF-like protein. Proc. Natl. Acad. Sci. USA. 83:68446848.

17. Gunther, S., R. W. Alexander, W. J. Atkinson, and M. A. Gimbrone, Jr. 1982. Functional angiotensin II receptors in cultured vascular smooth muscle. J. Cell Biol. 92:289-298.

18. Libby, P., and K. O'Brien. 1983. Culture of quiescent arterial smooth muscle cells in a defined serum-free medium. J. Cell. Physiol. 115:217-223.

19. Chirgwin, J. M., A. E. Pryzbyla, R. J. MacDonald, and W. J. Rutter. 1979. Isolation of biologically active ribonucleic acid from sources enriched in nuclease. Biochemistry. 18:5294-5299.

20. Stanton, L. W., R. Watt, and K. B. Marcu. 1983. Translocation, breakage and truncated transcripts of c-myc oncogene in murine plasmacytomas. Nature (Lond.). 303:401-406.

21. Betsholtz, C., A. Johnson, C.-H. Heldin, B. Westermark, P. Lind, M. S. Urdea, R. Eddy, T. B. Shows, K. Philpott, A. L. Mellor, T. J. Knott, and J. Scott. 1986. cDNA sequence and chromosomal localization of human platelet-derived growth factor A-chain and its expression in tumour cell lines. Nature (Lond.). 320:695-699.

22. Robbins, K. C., S. G. Davare, and S. A. Aaronson. 1981. Molecular cloning of integrated simian sarcoma virus: genome organization of infectious DNA clones. Proc. Natl. Acad. Sci. USA. 78:2918-2922.

23. Feinberg, A., and B. Vegelstein. 1982. A technique for radiolabeling DNA restriction endonuclease fragments to high specific activity. Anal. Biochem. 132:6-13.

24. DiCorleto, P. E., and D. F. Bowen-Pope. 1983. Cultured endothelial cells produce a platelet-derived growth factor-like protein. Proc. Natl. Acad. Sci. USA. 80:1919-1923.

25. Heldin, C.-H., G. Backstrom, A. Ostman, A. Hammacher, L. Ronnstrand, K. Rubin, M. Nister, and B. Westermark. 1988. Binding of different dimeric forms of PDGF to human fibroblasts: evidence for two separate receptor types. EMBO (Eur. Mol. Biol. Organ.) J. 7:1387-1393.

26. Walker, L. N., D. F. Bowen-Pope, R. Ross, and M. A. Reidy. 1986. Production of platelet-derived growth factor-like molecules by cultured arterial smooth muscle cells accompanies proliferation after arterial injury. Proc. Natl. Acad. Sci. USA. 83:7311-7315.

27. Nilsson, J., M. Sjolund, L. Palmberg, J. Thyberg, and C. H. Heldin. 1985. Arterial smooth muscle cells in primary culture produce 
a platelet-derived growth factor-like protein. Proc. Natl. Acad. Sci. USA. 82:4418-4422.

28. Escobedo, J. A., S. Navankasatussas, L. S. Cousens, S. R. Coughlin, G. I. Bell, and L. T. Williams. 1988. A common PDGF receptor is activated by homodimeric A and B forms of PDGF. Science (Wash. DC). 240:1532-1534.

29. Baserga, R. 1976. Hypertrophy and hyperplasia in multiplication and division in mammalian cells. Marcel Dekker, Inc., New York. 189-199.

30. Dzau, V. J. 1986. Significance of vascular renin angiotensin pathways. Hypertension. 8:553-559.

31. Asaad, M. M., and M. J. Antonaccio. 1982. Vascular wall renin in spontaneously hypertensive rats: potential relevance to hypertension maintenance and antihypertensive effect of captopril. Hypertension. 4:487-493.

32. Campbell, D. J., and J. F. Habener. 1987. Cellular localization of angiotensinogen gene expression in brown adipose tissue and mes- entery: quantification of messenger ribonucleic acid abundance using hybridization in situ. Endocrinology. 121:1616-1626.

33. Naftilan, A. J., R. E. Pratt, and V. J. Dzau. 1988. Localization and differential regulation of angiotensinogen mRNA expression in the vessel wall. Clin. Res. 36:553A. (Abstr.)

34. Cassis, L. A., K. R. Lynch, and M. J. Peach. 1988. Location of angiotensinogen messenger RNA in rat aorta. Circ. Res. 62:12591262.

35. Okamura, T., Miyazaki, M., T. Inagami, and N. Toda. 1986. Vascular renin-angiotensin system in two-kidney, one clip hypertension. Hypertension. 8:560-566.

36. Persson, H., and P. Leder. 1984. Nuclear localization and DNA binding properties of a protein expressed by human c-myc oncogene. Science (Wash. DC). 225:718-721.

37. Kindy, M. S., and G. E. Sonenshein. 1986. Regulation of oncogene expression in cultured aortic smooth muscle cells. J. Biol. Chem. 261:12865-12868. 